\title{
Pastoral leadership in a congregational church setting: The case of the Baptist Convention of South Africa
}

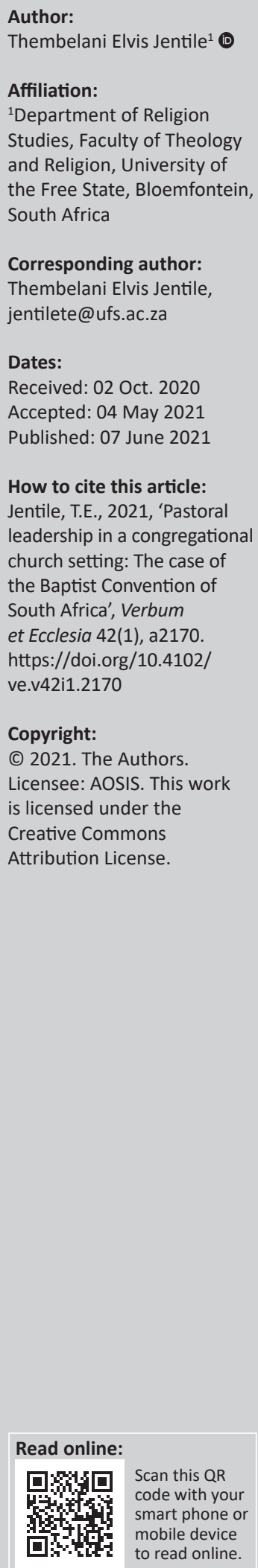

This study attempted to explore the role of pastors in a congregational church setting by using the Baptist Convention of South Africa (BCSA) as a case study. The focus is on the type of leadership relevant for such a system. A proper understanding of congregational church governance and biblical pastoral leadership is encouraged. It is argued that the BCSA would do well to adopt an attitude that views 'congregational church governance' as 'sacramental democracy', where church members view church meetings to be just as holy as any other sacrament, for example, a holy communion or baptism. Such an understanding of congregational governance offers an environment that is conducive to effective pastoral leadership. The pastor relates to the church as a biblical leader, who uses his or her authority to empower others, as the pastor is also under the authority of Jesus Christ as a follower.

Intradisciplinary and/or interdisciplinary implications: The study has significance for Christian Ethics, Practical Theology and New Testament. It is undertaken within (intra-) the Christian leadership discourse, with interest in Applied Ethics that combines Philosophical, Theological and Human Science approaches, especially with reference to (South) African sociopolitical and ecclesiastical contexts. The research builds on the existing Christian leadership discourse.

Keywords: Baptist; congregationalism; governance; pastoral; leadership; church; democracy; sacrament.

\section{Introduction}

This study seeks to examine the role of pastoral leadership in a congregational church. A pastor in a local church has at least three traditional roles, namely, to proclaim, to care for and to lead (Mosley 1973). It is the 'leading' part or the leadership role of the pastor that has always been of concern to the Baptist Convention of South Africa (BCSA). The BCSA has struggled with the concept of leadership and the role of the pastor in local churches (Klammt 2006; Kretzschmar, Msiza \& Nthane 1997) since at least 1987, when it decided to exist independently of the Baptist Union (BU). One of the questions is how to relate the role and authority of the pastor to that of other leaders in the church and the entire congregation. This struggle is observable in the Winter School of Theology discussions of the BCSA organised by the Baptist Convention College. In 1995, there were discussions and presentations on pastoral issues. Of note was a paper by Hoffmeister and Kretzschmar (eds. 1995:38) that reminded pastors to share leadership. Two years later, the Third Winter School of Theology in Magaliesberg, themed Being a Baptist in South Africa Today, discussed 'congregational church government' (Kretzschmar et al. 1997). Reflecting the concerns in local churches in general, participants raised questions such as 'What models of leadership are being used in our local churches and how are these understood (e.g. a shepherd, a chief and a servant)?' and 'What ought to be the relationship between the pastor, the executive committee, and the congregation as a whole?' (Kretzschmar et al. 1997:274-275).

From these questions and other pastoral leadership discussions, the reference to congregational church governance whenever Baptists talk about leadership in the church is observable. The principle of congregational church governance stresses the role of the congregation as a whole in deciding issues in the church (Msiza 1997:34). It is within the confines of this principle that a pastor is expected to lead effectively in a Baptist church. In this environment, it is difficult to define the leadership role of the pastor. Should a pastor assume an autocratic role and emphasise authority? Should the pastor employ democratic leadership and be participative? Or just be hands-off and avoid power and responsibility?

Klammt (2006:139) observed that in a congregational church, the role of leaders is defined by terms such as 'advisor' or 'facilitator'. Kretzschmar (1997:71) added another term, namely, 'coach'. 
If that is the case, how one leads as an advisor, facilitator or coach is important. Furthermore, it will be interesting to determine if the biblical 'shepherd theory' is sufficient to explain the role of a modern pastor. If not, what other theory can be useful for today's BCSA pastor?

\section{Research aim and method}

I have served the BCSA local church in Mamelodi, east of Pretoria. Having served the local church, I went on to serve the denomination at the national level, as the general secretary. Issues of leadership in the denomination have been of concern to me. The aim of this article is to construct a theoretical model of pastoral leaders of congregational churches. It conceptualises the congregational church governance principle and pastoral leadership model for a congregational church. The research is on pastoral leadership; the focus is therefore on leadership in a congregational setting. Congregational church governance is a principle under which Baptist churches are governed and pastors work; it is therefore examined in detail. This research hypothesises that congregational governance offers an environment that is conducive to effective pastoral leadership. This is contrary to a growing belief amongst young South African Christian church leaders that without power in decision-making, or at worst authoritarian leadership, the pastor cannot be an effective leader of a congregation. This study therefore seeks to answer the following questions: Who is the BCSA? What is congregational leadership governance? Is congregational church governance the same as democracy? If so, what form of democracy? What is meant by pastoral or shepherd leadership? Is the biblical 'shepherd theory' sufficient to explain the role of a modern pastor in a congregational church?

This work employed a theoretical research method. It utilised a literature review of relevant articles and books drawn mostly from the fields of Christian leadership and congregational church governance.

\section{The Baptist Convention of South Africa}

The BCSA was born as the Bantu Baptist Church in February 1927. It was born out of the missionary work of the German missionaries and British settlers amongst black people in the Eastern Cape (Makhanya 1990:33). 'In 1926 Rev. Mashologu challenged all known Black Baptist Churches in the Eastern Cape ... to come together to unite. Thus Bantu Baptist Church [was formed]' (Makhanya 1990:33). In 1966, it was called the Bantu Baptist Convention of Southern Africa, and in the same year, it made a formal application to the BU for association status. Later, its leadership felt it was wrong and unbiblical to remain racially segregated, and in 1968, the word 'Bantu' was dropped. It thus became the 'Baptist Convention of South Africa' (Makhanya 1990:35). One of the BCSA's senior pastors, the late Rev. Gideon Makhanya (1990), wrote:
In 1980 the Baptist Union, at its Assembly in Cape Town, gave the special associations (one of which was the BCSA) a period of six years, up to 1986, to dissolve and join the Baptist Union. (p. 36)

However, the BCSA resisted, not only because of racism and white dominance within the BU, but also because of the fact that the BU continued to be uncritical of the apartheid system in the country. The BCSA called for total transformation of the BU, whereas the BU suggested a 'merger' (Kretzschmar 1998:309-317). Eventually, in 1987, the BCSA cut ties with the BU and resolved to stand on its own. Early in 1998, the BCSA received full membership status from the All Africa Baptist Fellowship, and in July of the same year, it was accepted in the Baptist World Alliance.

\section{The Baptist Convention of South Africa's pastoral development}

These historical developments had an effect on the pastoral leadership of the BCSA and the running of churches, specifically the pastor's role within the congregation. It is important at this juncture to point out these effects. The Millard Baptist Training Institute was built in 1939 and opened in 1940 at Orlando in Johannesburg. It was later closed in November 1959, and in its place, the Baptist Bible Institute (BBI) was built, which was opened in February 1960. Subsequently, the Southern Baptist Convention, after the closure of the BBI, bought the property and turned it into a theological seminary known as the Baptist International Theological Seminary (BITS) (Matshiga 2001:63). It was at the BBI that most of the BCSA pastors, especially the older ones, were trained. Kretzschmar (1998:319) noted that Baptist Convention ministers 'were on a separate roll, and they were educated differently' from their white colleagues in the BU. Senior pastor and graduate of BITS, Mhlophe (1990), wrote that 'theological training of convention pastors was subjected to the standards imposed by the white Baptist Union' (p. 54).

Mhlophe lambasts this education as being inferior to that of white counterparts. The BCSA pastor was not necessarily equipped to lead a church, but only to preach, even though the education was often irrelevant to the churches and the people they were preaching to (Mhlophe 1990). The leading part was reserved for the white 'superintendent' who was visible in black church meetings (Mhlophe 1990:55) as an overseer. Mhlophe asserted that the presence of the superintendent in church meetings was to influence the proceedings, as the pastors were there at his mercy; at 'his mercy' because whenever a church needed a pastor, it had to be approved by the superintendent (Mhlophe 1990:55). Khanyile (2007) added that the relationship between African pastors and the superintendent was not a smooth one. The superintendents dictated what ought to be preached on the pulpit. In 1987, the same pastors, who were not properly trained to lead, and their disempowered members decided to stand on their own without the supervision of the superintendent and the BU. With such developments, the BCSA was bound to have challenges with regard to roles and expectations. Kretzschmar (2002) explained the long-term 
negative consequences of apartheid and abuse of power in South African churches. She wrote that because of the abuse of power under apartheid, church members developed 'wounded attitudes towards authority'. This is when followers regard themselves as either dependent beneficiaries or victims. Followers tend to have false expectations in treating leaders as all-knowing and able to provide whatever the followers require (Kretzschmar 2002:50). This 'wounded attitude' has also led some to treat anyone in leadership with suspicion, which makes it difficult for leaders to execute their duties. Furthermore, disempowered church members lose self-esteem and confidence, which leads to dependent Christians who refuse to take responsibility for the practice of their faith. 'This results from infantile religion, that is, religion practiced by immature person' (Kretzschmar 2002:48). The consequences are that the pastor is seen as the only person who is in ministry and the congregants as mere spectators.

These challenges are clearly seen 10 years after the BCSA's independence from the BU, at the Winter School of Theology in Magaliesberg (Kretzschmar et al. 1997). Just by observing the papers discussed at Magaliesberg, one would see that tensions between the pastors and the churches were already at boiling point. There were papers such as 'The Pastor and Church Relationships', 'Baptist Church Government' and 'Personality Types and Leadership Styles'. These leadership struggles were also observed by Klammt 20 years later - that 'the concept of leadership and with the question how to relate the authority of the pastor to that of the church executive and of the congregation' (2006:140) is a serious challenge for the BCSA. The BCSA hasn't done much to rectify these leadership challenges since 1987 . However, the denomination has tried to use the Winter School of Theology and the Baptist Convention College as platforms where ministers can be trained in congregational church governance, yet very few pastors and ordinary members attend to these mentoring sessions.

\section{The Baptist Convention of South Africa and congregational church governance}

As a denomination, the BCSA subscribes to the principle of 'congregational church government' as it appears in the Statement of Baptist Principles (Kretzschmar 1998:349-350), adopted in October 1987:

The principle of Congregational Church Government, namely, that a constituted church meeting is, under the Lordship of Jesus Christ, the highest court of authority for the local church; and that each individual member has the inalienable right and responsibility to participate fully in the life and government of the Church, including the appointment of its leaders. (Baptist Union of South Africa 1877:178)

Almost all Baptist churches govern their affairs in a similar fashion, by adhering to the congregational church government. Pell (1993:24) perceived, in Zambia, that 'in keeping with Baptist practice, Church government is usually exercised through quarterly church member meetings and an annual meeting where elections are held for elders and deacons'.

In French Baptist churches, Parker (1982) reports that decisions are made in a similar way to the South African context:

Every local Church must herself manage her own affairs, independent of all other political or religious authority. As far as accepting candidates' baptism and dealing with questions of business, a final vote should be taken. All members, without any distinction of sex or position, hold equal rights in church and a decision is taken as a result of a majority vote. (p. 131)

The Spanish churches call this process 'democratic'. 'This church is an autonomous body, operating through democratic processes under the Lordship of Jesus Christ. In such a congregation, members are equally responsible' (Parker 1982:250).

Congregational church governance has received a great deal of attention from the BCSA as it impacts directly on pastoral leadership. The Baptist World Alliance president, Rev. Paul Msiza, in defining the principle, raises some concerns and suggestions around the contextualisation of Baptist principles in general, and congregational church governance in particular (Kretzschmar 1997:58-64). Msiza (1997:58) wrote that 'this principle is self-explanatory; it simply means the congregation makes decisions that govern the church'. The congregational system stresses that each believer has a responsibility towards leading and nurturing the local church (Kretzschmar 1997:34). Shelley (1989) noted that congregational churches are experiencing major changes today in the ways that their congregations function. Questions of pastoral power are of concern. Shelley starts by defining congregationalism as a church polity that arose in 16th-century Puritanism and stresses the gathered church principle. According to Shelley (1989), congregationalists moved through four basic periods of significant change as the American culture changed. Congregational churches seem to be more susceptible to cultural changes simply because they are more 'democratic' and therefore more likely to reflect common values.

The four periods mentioned by Shelley (1989) shed light on the development of congregational churches in South Africa, especially the BCSA. The researcher's assertion is that the BCSA has gone through some of these stages. The first period, 1620-1690, is classical congregationalism. The Puritans gave the BCSA an ideal of common life for the gathered church and the participation of every member in the worship, ministry and authority of the church (Shelley 1989). The second is from 1800 to 1860 , which is evangelical congregationalism; the evangelical age added emphasis to the spiritual rights of the individual, the right to decide for or against Christ, and to view the church as a means to personal ends. It was around this time that South Africa became a target of evangelism and colonisation by early European missionary societies (Makhanya 1990:33). The third is managerial congregationalism 
(1880-1930). The managerial age brought a passion for methods, programmes and an admiration for numerical success. For the better part of its history, the BCSA was under the administration and watchful eye of white men; first under German missionaries and British settlers, and later the South African Baptist Missionary Society. Methods and programmes were the order in worship services:

By the second half of the nineteenth century, Christian congregations of Anglicans, Baptists, Congregationalists, Methodists, Presbyterians and Roman Catholics had spread throughout the colony, so that the need for some coordinating central organizations within various denominations had become apparent: institutional consolidation was characteristic of the 1870s and 1880s at the Cape. (Hofmeyr \& Pillay 1994:124)

This stage is relevant for this discussion. With the shifting of life, from the small towns to the new centres of commercial and industrial power, 'new conditions demanded new thinking and none more significant for the churches than "business thinking"' (Shelley 1989:45). This shift resulted in organisational, bureaucratic systems, which valued efficiency and scientific management. The major effect of this stage was on the leadership style of the local church:

In the 'managerial age', pressure mounted on the local pastor and his people to think of the church as 'God's business' and the minister as a church manager ... the 'business mentality' seemed to fit the congregation. The minister is the chief executive officer, the board established policy; the body adopts the budget; and the members are mobilized for church growth or social service. (Shelley 1989:46)

The terminology changed from 'church meeting' to 'business meeting'. This change is significant for two reasons, which are both relevant to this discussion. The first is the impartation of the word 'business'. Would unreflective adoption of this term not violate the biblical mandate of disciple making rather than 'profit' making? Will churches not begin the separation of the 'spiritual' and 'business', as has been observed in some local churches? Business meetings are run like political meetings, whilst a spiritual meeting consists of prayer, scripture reading and preaching, which are seldom seen in 'business' meetings, therefore leading to a separation between faith and 'real life'. The second challenge is that mentioned by Shelley (1989), who correctly observed that:

Managers need not only authority. They need power. If authority is the right to make decisions, power gives the ability to carry them out. In the congregational church, where decisions are supposed to be carried out collectively and voluntarily, power isn't appropriate. (p. 47)

Does this mean that the BCSA has reached a managerial congregational stage, because these challenges are observable? Where does authority lie in a congregation, and how can one best exercise authority in a managerial age? Can we say that the pastor's frustrations or the mutual confusion of the pastor and the congregation are understandable, considering the changes that come with this stage of congregationalism?
The last stage is therapeutic congregationalism (1940-1980). The age of therapy focused on the church as a refuge of comfort, care and healing for hurting individuals (Shelley 1989:49-50). Pastoral leadership here is expected to be the healer of wounded spirits. The BCSA still continues to minister in this fashion. Mhlophe (1990:57) wrote that 'I was personally challenged in a recent conference which was discussing the Church's role in relation to the imminent return of South African exiles'. The BCSA through its ministers had a challenge of ministering to the hurting and the downtrodden. How well the BCSA has done this is debatable. The danger with this stage is the limitation of pastoral duties to preaching and counselling. But pastoral duties include leading, which means giving direction to the congregation. Shelley's model is incomplete in the sense that one also needs a prophetic model that enables the church to critique itself and to speak and act prophetically in society by challenging the very systems that hurt people. Caring and prophetical witness ought to go together. If you care, you need to ask why people are suffering.

\section{Congregationalism: Its weaknesses and strengths}

In defining congregational church governance, Kretzschmar (1997) also discussed its weaknesses and strengths. Kretzschmar alluded to the fact of unchristian attitudes from church members, especially those powerful individuals who are deacons, elders or members of church committees who can cause misery in the pastor's life or that of his or her family (Kretzschmar 1997:35). Members can go to the extent of disapproving of the pastor's vision for the church. Msiza (1997) agrees that congregational church governance:

Can promote the exploitation and oppression of the leadership. This can happen when the church chooses to disregard the position and the responsibility placed upon the leadership. This can retard progress in churches where this principle is misunderstood. (p. 62)

The solution to the abuse of this principle is that leaders and congregants be properly educated and empowered in order for all members to use their God-given talents for the benefit of all. The advantages of congregational church governance are ample. In fact, in group discussions at the 1997 Winter School of Theology, it was said that the proper application of this principle would help pastors to fulfil their vision without constraints. The principle also prevents the misuse of power by pastors, as it calls for checks and balances and maximum participation by the congregation. Kretzschmar (1997:62) wrote that this principle 'propagates quality growth because of the liberty given to every member to have responsibility in the area of decision making'. The researcher agrees that when people are empowered in the area of their God-given talents, they tend to grow as individuals in the Lord and in their relationships with others. Lastly, what 'this principle affirms is the freedom that we find in Christ' (Kretzschmar 1997:62). Every disciple's goal is not only to be like Christ but also to be used by Christ in his church and the world. Therefore, it is every believer's privilege to speak to God and be spoken to, 
and for one to be part of decision-making processes of the body of Christ. Ephesians 4 speaks of the equipping of the saints for the work of ministry (inside and outside the church).

\section{Congregationalism as 'sacramental democracy'}

What is of concern in Msiza's definition is the assertion that congregational church governance 'is the democracy in the local Church' (Msiza 1997:58). He is not, however, the only one to use the term 'democracy' to describe this principle. The researcher noted earlier that Spanish churches also use the same term when defining congregational governance (Parker 1982:250). Scholars such as De Gruchy (1994) noticed the importance of the church in ushering in a democratic culture. Pityana (1995:91) suggested that the church, referring to its leadership, must 'learn fast the rudiments of democracy'. A question can be raised on whether the term 'democracy' describes the Baptist church structure appropriately. Baptist historians and theologians have held varied opinions on the propriety of identifying the 'gathered church' or 'congregationalist' model as 'democracy', as argued by Schelin (2012). Some deny that 'the intention to live under the authority of Christ is properly named by a term denoting the rule of people' (Schelin 2012:23). The second criticism is actually the "fear that "democracy" means an institutionalization of rote business or parliamentary procedures that empty ecclesial discernment of spiritual and moral power' (Schelin 2012:24).

The argument is that the use of the word 'democracy' imports alien modes of decision-making and discernment into the body of Christ. What form of democracy is exercised in congregational churches? Schelin (2012) theologically reconfigured the concept of democracy in Baptist churches. He concluded that Baptist congregationalism is democratic but not properly in the form espoused by liberalism. He suggested sacramental democracy, which means that a church meeting is as holy as the holy communion or other sacramental meetings such as baptism. 'In other words, the church gathers not just as a political community but as a sacramental community' (Schelin 2012:31). Schelin (2012) explains:

Dedicated as a holy activity, then, congregational discernment and decision making is taken up by the Spirit and transformed into something greater than it can be as simply a human process. Through submission, attentiveness, and obedience, congregational politics becomes what may be called sacramental democracy. (p. 31)

Furthermore, Schelin (2012) asserted that:

The church gathers to listen and so seeks to be faithful to her Lord; however, the Church also gathers to decide and act upon the trust that has been given to her. (p. 31)

A clear biblical example is how the church dealt with conflict, reached agreement and restored unity in Acts 15 . The verdict was: 'It seemed good to the Holy Spirit and to us...' (Ac 15:28). The verse shows the fact of collaboration between the Spirit and the church. The relationship is that of a partnership of freedom; God enables the church to be more and more true to who they are as redeemed human beings. Msiza (1997:59) added another relevant passage when he wrote that congregational leadership is based upon scriptural verses such as Acts 6:1-7 - the choosing of deacons. Human beings, in a sense, had to make a decision after discussion and listening in prayer and discernment.

\section{Congregationalism in an African context}

The last issue that Msiza raised is that of contextualising congregational church governance. Magesa, as quoted by Kretzschmar (2002:43), also noted that 'we cannot ignore the influence of African religion and culture on present day African Christians'. Mugabe (1995:7) echoed the same sentiments at the 1995 Winter School of Theology - that Africans 'must articulate our faith considering our unique cultural, social and historical context'. When tackling traditional leadership, there is a tendency to suggest that tribal leaders are hierarchical, authoritarian and autocratic. Kretzschmar (2002:45) argued that ' $[\mathrm{t}]$ he notion that traditional African rulers were all autocrats... needs to be dispelled'. She is supported by Boon (2007), who observed that the:

Chief is not autocratic and must rely on councilors representing the people to assist him. The chief must be guided by consensus. If he is not, the people will ignore his decision or his law. The people must always be strongly represented, and the entire community should attend court or 'hearings'. (p. 44)

Checks and balances existed in tribal leadership (Kretzschmar 2002:44); however, under colonial government and apartheid, chiefs were appointed by and accountable to the government (e.g. Matanzima in the Transkei) and not answerable to the people. Hence, they were dictators. To test participatory decision-making in the African context, a study by Ngambi (2004:107-132) on African leadership discussed the Fungwe chieftaincy in Zambia's Mafinga district. This study was based on observation, conversations and interviews with Chief Mwenechifungwe and another headman, Chakosamoto, along with several villagers. Ngambi observed the Fungwe community and found these characteristics in the village leadership that leadership was through dialogue and shared vision; leadership fostered discipleship, not followership; and the chief was an overseer and custodian of the community. If congregational church governance is contextualised, using the model of chieftaincy, then the pastor has the following duties: feed the congregation, maintain peace, promote discipleship values, promote economic furtherance of the congregation, and preserve and defend life. The pastor is required to oversee every aspect of the mission of the church and to be faithful and accountable to God and the people.

\section{Pastoral leadership challenges}

Congregations are the pastor's leadership arena, and they are very challenging. Dale (1986:20) gave three reasons why congregations are challenging: firstly, a congregation is a volunteer organisation. As such, congregations are amongst 
the most sophisticated organisations that humans can design. Secondly, volunteers join and participate for a range of motives. Their motivations are more altruistic and service oriented than most employees in commercial places. Lastly, participative methods fit organisations and other volunteer agencies best. Additionally, Banks and Ledbetter (2004) added that:

Leadership is central concern in any democratic and bureaucratic society. This is also the case in church life, which is more democratized and bureaucratic than in previous times ... the issues of leadership influences attempt to understand chains of command and lines of authority. (p. 36)

The pastor's personal leadership style is therefore extremely important. Today, a pastor's role is not only important, it is complicated as well. In fact, one begins to critically ask if the 'shepherd' or 'pastoral' model, with all its good characteristics and intentions as mentioned in the scripture, is sufficient to meet the pastoral expectations of the day. Klammt (2006) stated that:

There is a logical weakness of the metaphorical use: the image suggests an ontological difference between 'shepherd' and 'sheep' that is not applicable for the relationship of pastor and church member. (p. 162)

The model of the shepherd does not provide a comprehensive picture of the relationship of the congregation with its leaders. Firstly, people are not sheep; they have a choice to follow or not to follow. Secondly, the pastor is not the only leader in the church, and other leaders have their own personal leadership styles. Also, Liftin (1982) is of the opinion that the model of the shepherd is not intended to be a complete model for the pastoral ministry:

That is why the term 'pastor' is buttressed by other terms such as 'elder' (1 Tim 5:1, 17; Titus 1:5; James 5:14; 1 Peter 5:1) and 'overseer' (Acts 20:28, Phil 1:1; 1 Tim 3:1; Titus 1:7). (p. 58)

Liftin further noted that the 'shepherd' image is evocative, but imprecise; instructive but incomplete.

\section{Biblical model of leadership (New Testament)}

At this point, it is important to examine the New Testament biblical model of leadership as it incorporates the 'elder', 'overseer' and 'pastor' to determine if one can identify the biblical characteristics of a congregational leader. The term 'pastor' is originally a Latin word that translates to 'shepherd' in English. The word 'shepherd' appears in the Old and the New Testaments, literally describes the profession of taking care of sheep and metaphorically refers to leaders (Ezk 34) of the people or even to God (Ps 23; 80:1) and Christ (Jn 10). However, it must be noted that in terms of pastoral leadership, the New Testament uses different terms: 'Rulers' (Heb 13:7), 'Those who are over you' (1 Th 5:12), 'Pastors/shepherds' (Eph 4:11), 'Elders' (Tt 1:5) and 'Overseers or bishops' (1 Tm 3:1; Phlp 1:1). The three descriptive terms - pastor, bishop and elder - are employed in the New Testament to depict the role of the pastor as the congregational leader. Notably, all three terms are used in Acts 20:28 and 1 Peter 5:1-4, although in 1 Peter, two are used in verb form. In Acts 20:28, Paul was speaking to the Ephesian 'elders' (V. 17). In verse 28, he spoke of them as 'overseers [bishop], to feed [as a shepherd] the church of God'. 1 Peter 5:1-4 further proved the relationship of these three terms:

The elders which are among you I exhort, who am also an elder... feed the flock of God [as shepherds] ... taking the oversight [bishop]... neither as being lords over God's heritage, but being examples to the flock. And when the chief Shepherd shall appear, you shall receive a crown of glory that faded not away.

The term 'elders' (presbuteros in Greek), which involves age (Ac 2:17), generically refers to a fully mature person. The respect accorded to an elderly person and wisdom is transferred to the office of the pastor (Hobbs 1964:85). The use of the word 'elder' indicates profound respect and esteem for the office. In the New Testament, members of the Sanhedrin, who were usually older men, were referred to as 'elders' (Mt 16:21, 26:47, 57, 59), but its Christian use refers to one who presides over local assemblies or local churches (Ac 11:30, 14:23; Tt 1:5; 2 Jn 1).

'Feed the flock of God' employs the Greek verb 'poimainoy', which means 'to shepherd' (Jn 21:16; Ac 20:28). The nominal form of the word 'elder' means 'to shepherd'. The word describes the spiritual ministries of the leader of the church. As the pastor or shepherd, he or she must feed or teach (2 Tm 2:22; 1 Th 5:12, 13; 1 Tm 5:17), care for (Ac 20:28; 1 Pt 5:1-3), guide and protect (Ac 20:28; $2 \mathrm{Tm} 2: 24 ; 1 \mathrm{Th} 5: 14$ ) and pray for the flock of God.

'Taking the oversight' is a translation of the Greek 'episkopountes', which means 'to oversee'. The noun form 'episkopos' usually translates to 'bishop'. In Greek life, it referred to one charged with the duty of seeing that things done by others were done correctly. In the New Testament, it denotes one charged as the overseer of a local church (Ac 20:28; Phil 1.1; 1 Tm 3:2; Tt 1:7). The emphasis is upon the administrative responsibilities of the chief officer of the church. Hull (1994:77) stated that the elder's function of 'oversight' is to rule ( $1 \mathrm{Tm} 5: 17 ; 1 \mathrm{Th} 5: 12$ ), to labour (the responsibility requires work) and to lead (Heb 13:7, 17, 24).

The terms are all synonymous in that they refer to the same office. They differ only in emphasis. These responsibilities are to be discharged willingly as an example (tupoi in Greek) to the flock, and they are not to be rendered because of constraint, but as a result of desire. How does a pastor relate to the congregation, and what are the characteristics of such a leader?

\section{The congregational pastor is a leader}

The observation from the text is that a pastor is charged with 'taking the oversight (bishop)' (1 Pt 5:1-4) role. The congregational pastor is a leader. This may sound obvious, but there are people who think that shepherds should not 
lead but only care for the sheep. Young (1985) argued that the primary responsibilities of the pastor in a local church are to provide leadership and teach, as did Timothy and Titus. He further quoted the verbal exchanges between Jesus and his disciples found in John 21:15-17. In that text, Jesus asked Peter to 'tend my sheep' and 'shepherd my sheep'. The combination of the words used by Christ is important. Young (1985) noted that:

The word bosko (feed or tend) simply means to 'provide food' while the word poimaino (to act as a shepherd) more broadly refers to 'guiding, guarding, folding of the flock, as well as finding of nourishment for it'. (p. 333)

Therefore, the apostle Peter was to feed the lambs and the sheep. However, he also had a wider responsibility to lead the flock in every aspect of its existence (Young 1985:333). However, a pastor is a servant leader and ethical leader. Jesus Christ, the chief shepherd, left the pastor with an unmistakable model of Christian servant leadership when:

He laid aside outer garments, and taking a towel, tied it around his waist. Then he poured water into a basin and began to wash the disciple's feet and to wipe them with the towel that was wrapped around him. (Jn 13:4-5)

Servant leaders take up Jesus' towel of servanthood to meet the needs of others:

He took up the towel and wash basin of a slave to model his mission and show his love for those he recruited to carry out that mission after his ascension. (Wilkes 1998:26)

If one takes, for example, the context that led to the writing of 1 Peter, it is clear that a pastoral leader must be a courageous person. Duling (2003) said this letter was written to express concern for, solidarity with, and encouragement of believers at a time when the Roman church was growing in importance:

A fiery ordeal is taking place among them (1 Peter 4:12); they are to resist the devil, and this suffering is being experienced by all Christians throughout the world (1 Peter 5:8-8). (p. 472)

Schnelle (1998:404-405) added that, one is called to protect and guard the flock against wolves and ravenous animals. Congregational leaders must be both servant leaders and courageous leaders.

\section{The congregational pastor is an empowering teacher}

It was noted earlier that a shepherd has the role of feeding and leading. It is to the 'feed the flock of God' (as shepherds) role that we now turn. Balswick and Wright (1988:3) stated, 'From a biblical perspective all styles of leadership must be characterized by an attempt to empower, rather than to dominate and control'. Furthermore, they noted that empowering is the biblical model for the use of power, as Paul stated in Ephesians 4:11-12 (Balswick \& Wright 1988:6). 'To equip God's people for work in His service, to the building up of the body of Christ' (Eph 4:12) refers to 'leadership as empowering - the use of power to increase the maturity of another for Christian ministry' (Balswick \& Wright 1988:6).
The pastor is an empowering teacher. The teaching that a pastor does is not necessarily preaching and/or lessons in church or a class room; it is about 'being examples to the flock' (1Pt5:4), that is, leadership by exampleor demonstration.

Hull (1990) observed three stages of reproduction in the disciple-making process in 1 Thessalonians 1:5-8. The first stage is 'demonstration': ' ... you know how we lived among you for your sake' (1:5). Disciples need to have behaviour modelled before them so they can visualise the desired attitudes and behaviour (Hull 1990:137). The second stage is 'imitation': 'You became imitators of us...' (1:6). All believers are called to imitate other believers, Christ and God. Human imitation ranges from simple comparison with the conduct of other believers (1 Th 2:14) to the presentation of examples of conduct to imitate (Phlp 3:17; 2 Th 3:7, 9; Heb 6:12, 13:7). The third stage is that of 'reproduction': 'And as you became a model to all the believers in Macedonia and Achaia... your faith in God has become known everywhere' (1 Th 1:7, 8). Reproduction takes place when the disciple becomes a model.

\section{The congregational pastor is a follower}

In congregational leadership, Jesus is the chief shepherd (1 Pt 5:1-4) and the pastor is the under-shepherd. Anderson is quoted as having said:

The bible says comparatively little about leadership and a great deal about followership. Jesus did not invite Peter, Andrew, James, and John to become leaders immediately. He said, 'Follow $\mathrm{Me}^{\prime}$. (Wilkes 1998:60)

Banks and Ledbetter wrote that leadership that bears the imprint of faith includes followership. 'Leadership is never devoid of good followership. The faithful leader is a servant first, and from that emerges the desire to lead' (Banks \& Ledbetter 2004:55). In his article on discipleship as leadership, Copeland (2013) emphasises that he is drawn to leaders who follow as much as they lead:

The distinction can be difficult to detect, as it's usually a matter of disposition, self-awareness and spiritual practice. But the fact is that God calls all of us to follow Jesus Christ. (p. 11)

\section{Remarks for the Baptist Convention of South Africa}

The ministry that the BCSA gives to its pastors needs to be taken seriously, and the spiritual and moral formation of leaders and discipleship in general must be emphasised.

\section{Correct understanding of congregational church governance}

Congregational church governance as a system is not a problem. It is a valid principle; however, there seems to be no profound understanding of the system, and how it can be utilised to the benefit of the church and the advancement of the Kingdom of God. One can recommend that the BCSA must try to practise what is called 'sacramental democracy' (Schelin 2012). As stated above, sacramental democracy means that a church 
meeting is as holy as the holy communion or other sacramental meetings such as baptism. The church gathering is not just a political meeting but a sacramental meeting. Sacramental democracy discourages dualism, which is rife in Christian ministries. People tend to separate what is holy (e.g. holy communion) from what is unholy (e.g. church business meeting). The principle of congregational church government suggests 'that a constituted church meeting is under the Lordship of Jesus Christ', which makes the church gathering holy. Value is therefore placed on submission, attentiveness and obedience. The church business becomes God's business, as Jesus once said ( $L k$ 2). Attitude is just the beginning; discernment is the following step. The entire congregation learns to listen in prayer to the Lord. We also listen to one another as we decide and act upon the trust that Jesus has given to us. In such meetings, decisions are made through dialogue, and issues are discussed until consensus is reached.

\section{Better practice of the biblical model of leadership}

The church as a sacramental community offers a conducive environment for effective biblical pastoral leadership. Firstly, it is important to note that when it comes to leadership, there are two opposing systems in the world, 'the cosmos' and 'the kingdom' (Cole \& Helfer 2012:116). Cosmos is the system by which the world operates. In the cosmos system, power is based on position, with those on top wielding it over those beneath them. Jesus Christ warned the disciples that 'You know that the rulers of the Gentiles lord it over them and their great men exercise authority over them. It is not so among you' (Mt 20:25). Jesus is telling his disciples that leadership amongst them is different from the system of the world. In the Kingdom of God, leadership is not about the top-down exercise of authority or control as is seen in most businesses (Cole \& Helfer 2012:117). To explain this difference further, Collins (2006) hypothesises that there are two types of leadership skills: executive (mostly in the business sector) and legislative (mostly in social sectors). Collins (2006) wrote that:

In executive leadership, the individual leader has enough concentrated power to simply make the right decisions. In legislative leadership, on the other hand, no individual leader not even the nominal chief executive - has enough structural power to make the most important decisions by himself or herself. (p. 11)

It seems, as Collins (2006:11) expressed, that leadership in the church is more legislative than executive, because it relies more on persuasion and shared interests to create the conditions for the right decisions to be made.

\section{The pastor as a leader}

The biblical leadership model dictates that a pastor be a leader in the church. Terms such as 'elder' and 'overseer' underscore the importance of leadership as part of pastoral identity. Leadership is not optional for a local church, because leaders must provide more direction and structure for new or young members. Although called by God into ministry in general, the BCSA pastor is called by the local congregation into a particular church. Therefore, as a congregational leader, one must show the following essential characteristics, as mentioned by Johnson (1995:198-200): to impart a vision (or lead the process of discovering a vision for the congregation), to steward the resources and to lead in [spiritual] battle. One could add that a BCSA pastor ought to be a leader in the disciple-making process. Schmidt (1979:5) suggested that a pastor be a 'playing coach'; in other words, the pastor is part of the team and that is a collaborative, participatory and shared leadership. Furthermore, the leadership role of the pastor dictates that one exercises a certain level of authority in the church. Christian authority is delegated authority, as it comes from above (Kretzschmar 2009). Therefore, it ought to be used for the care and benefit of the ministry, and not for selfish ambitions. Harris' (ed. 1976) explanation of religious authority is profound. He called the authority in the church a 'Representative Religious Authority' (ed. Harris 1976:136) or an individual 'who stands' for ultimate religious authority. He proposed the following definition of 'Representative Religious Authority':

$\mathrm{Y}$ may be said to have religious authority over $\mathrm{X}$ if $\mathrm{X}$ is convinced that $Y$ is the correct representative of the deity or has the power of the ultimate force or forces of the universe representatively embodied in him to some degree.... (ed. Harris 1976:136)

The BCSA should emphasise the correct understanding of pastoral authority.

\section{The pastor as a teacher}

The biblical model of the pastorate suggests that one be an empowering teacher. Onecanthenmaketworecommendations for the BCSA. Firstly, pastors should be prepared to move from 'control' to 'empowerment' (Gibbs 2005:88). The reason many pastors do not want to empower people is that empowering others inevitability means yielding one's own power. Gibbs (2005:88) observed that delegation is not enough if it is not linked with the empowerment of others, which may result in a loss of control. Secondly, a BCSA pastor should be able to communicate the important truths of Christ to others. One must therefore study, preach, teach and witness to the Bible's teaching with urgency (1 Tim 4:13; 2 Tim 2:15, 4:2-5), confront bad religion with strong teaching and personal faith (1 Tim 1:3-20; Tt 1:5-16), never be selective when you pray for or witness to God's creatures (1 Tim 2 2:1-8), be willing to pay the price for faithful proclamation (2 Tim 3-12) and to let one's life and faith be a public and private example (1 Tim 3:1-7, 4:12; 2 Tim 2:22; Tt 1:6-9).

\section{The pastor as a follower}

The biblical model of leadership showed that a pastor is first and foremost a follower. In fact, leaders both lead and follow. As a follower, the BCSA pastor is expected to be teachable. One must learn from the Lord Jesus through the pages of the scripture and follow his attitude and behaviour. Learning from Christ demands that a pastor practises certain spiritual disciplines such as studying the scripture, 
spending time in prayer and worship and taking time for extended periods of solitude, meditation and fasting. A pastor would do well to also learn from other pastors, especially mentors. Oates (1987:21) wrote that a pastor can have integrity and answerability and still have hermetically sealed minds, be unteachable, hearing only what he or she wants to hear, and selectively blocking out anything that does not fit their set of clichés. A pastor who is not learning will find it difficult to positively influence the congregation. The BCSA pastor as a follower of Christ must also be an ethical leader:

An ethical leader is someone who has integrity (an honest and integrated person) and can be trusted. Such leaders are able to encourage development of the moral identity and courage of others. They are motivated by moral norms and values such as justice, compassion and peace, rather than building empires of self-glorification. (Kretzschmar 2005:107-108)

The integrity of Christian leaders is measured by their sense and use of power in relation to others (Oates 1987:19).

One cannot emphasise enough the importance of accountability from BCSA pastors. Some leaders say that they are not accountable to the church but to Jesus Christ. What they are missing is that the church is the body of Christ (1 Cor 12). Hull (1994) argued that:

\begin{abstract}
You can't make disciples without accountability. To believe you can is like believing that you can raise children without discipline, run a company without rules, or lead an army without authority. (p. 159)
\end{abstract}

When leaders fail to account, they fail to lead. Accountability is a means for quality control; it protects the church and helps people to keep their commitment to God.

\section{Conclusion}

This study attempted to explore the role of a pastor in a congregational church. The focus was on the type of leadership relevant for such a system. It concluded that the BCSA would do well to adopt an attitude that views congregational church governance as sacramental democracy, where church members view the church meeting to be just as holy as any other sacrament, such as a holy communion or baptism. The study further concluded that such an understanding of congregational governance offers an environment that is conducive to effective pastoral leadership. The pastor relates to the church as a biblical leader, who uses his or her authority to empower others as the pastor is also under the authority of Jesus Christ as a follower. The nature and bounds of this study prohibited expanding into other areas, such as discipleship. 'Discipleship' is related to congregational church governance. A study can be conducted on the BCSA that examines the systems used in BCSA churches where teaching, training and evangelism take place. Another study could dwell on traditional leadership's influence on BCSA pastors. This study touched on that, but only in passing.

\section{Acknowledgements Competing interests}

The author declares that he has no financial or personal relationships that may have inappropriately influenced him in writing this article.

\section{Author's contributions}

T.E.J. is the sole author of this research article.

\section{Ethical considerations}

This article followed all ethical standards for research without direct contact with human or animal subjects.

\section{Funding information}

This research received no specific grant from any funding agency in the public, commercial or not-for-profit sectors.

\section{Data availability}

Data sharing is not applicable to this article as no new data were created or analysed in this study.

\section{Disclaimer}

The views and opinion expressed in this article are those of the author and do not necessarily reflect the official policy or position of any affiliated agency of the author.

\section{References}

Balswick, J. \& Wright, W., 1988, 'A complementary-empowering model of ministerial leadership', Pastoral Psychology 37(1), 3-14. https://doi.org/10.1007/ BF01763913

Banks, R. \& Ledbetter, B., 2004, Reviewing leadership, Baker Academic, Ada, MI.

Baptist Union of South Africa, 1877, The South African Baptist handbook, Baptist Union of South Africa, Cape Town

Boon, M., 2007, The African way, Zebra Press, Cape Town.

Cole, N. \& Helfer, P., 2012, Church transfusion: Changing your church organically From the inside out, Vol. 63, Jossey-Bass, San Francisco, CA.

Collins, J., 2006, Good to great, Random House, London.

Copeland, A.J., 2013, 'Why lead? Discipleship as leadership', Christian Century (November), 11-12.

Dale, R.D., 1986, 'Leadership-followership: The church's challenge', Southwestern Journal of Theology 29(2), 23-28.

De Gruchy, J., 1994, 'Midwives of democracy: The role of churches in democratic transition in South Africa', Journal of Theology for Southern Africa 86(1), 14-25.

Duling, D.C., 2003, The New Testament: History, literature, and social context, 4th edn., Thomson Wadsworth, Belmont, CA.

Gibbs, E., 2005, Leadership next, Inter-Varsity Press, Downers Grove, IL.

Harris, R.B. (ed.), 1976, Authority: A philosophical analysis, University of Alabama Press, Tuscaloosa, AL.

Hobbs, H.H., 1964, What Baptists believe, Broadman Press, Nashville, TN.

Hoffmeister, D. \& Kretzschmar, L. (eds.), Towards a holistic, Afro-centric and participatory understanding of the gospel of Jesus Christ, BCSA, Johannesburg.

Hofmeyr, J.W. \& Pillay, G.J., 1994, A history of Christianity in South Africa, Vol. 1, HAUM Tertiary, Pretoria.

Hull, B., 1990, The disciple making church, Fleming H. Revell, Grand Rapids, MI.

Hull, B., 1994, The disciple making pastor, Fleming H. Revell, Grand Rapids, MI.

Johnson, E.J., 1995, 'The Old Testament offices as paradigm for pastoral identity', Bibliotheca Sacra 152(April-June), 182-200.

Khanyile, S., 2007, 'KwaZulu-Natal', in N.E. (ed.), Journeying with God: The history of the Baptist Convention of SA from 1987-2007, BCSA, Johannesburg. 
Klammt, T., 2006, 'A systematic theological investigation of the marks of the pastor according to contemporary Baptist theology in South African and German contexts', PhD thesis, University of South Africa, Pretoria.

Kretzschmar, L., 1997, 'An overview of Baptist principles in historical context', in L. Kretzschmar, P. Msiza \& J. Nthane (eds.), Being a Baptist in South Africa today, pp. 16-52, BCC, Johannesburg.

Kretzschmar, L., 1998, Privatization of the Christian faith: Mission, social ethics and the South African Baptist, Legon Theological Studies Series, Accra.

Kretzshmar, L., 2002, 'Authentic Christian leadership and spiritual formation in Africa' Journal of Theology for Southern Africa 113(1), 41-60.

Kretzschmar, L., 2005, 'Spirituality, discipleship and leadership: Evangelical challenges', in L. Kretzschmar \& M. Ntlha (eds.), Looking back, moving forward: Reflections by South African evangelicals, pp. 101-117, The Evangelical Alliance of South Africa, Johannesburg.

Kretzschmar, L., 2009, 'The call to moral, life-giving leadership', in L. Kretzschmar, W. Bentley \& A. Van der Niekerk (eds.), What is a good life? An introduction to Christian ethics in 21st century Africa, pp. 157-179, Acad SA Publishing, Kempton Park.

Kretzschmar, L., Msiza, P. \& Nthane, J. (eds.), 1997, Being a Baptist in South Africa today, BCC, Johannesburg.

Liftin, D., 1982, 'The nature of the pastoral role: The leader as completer', Biblioteca Sacra 139(553), 57-66.

Makhanya, G., 1990, 'History of the Baptists convention of Southern Africa', in D. Hoffmeister \& B. Gurney (eds.), The Barkly West national awareness workshop, pp. 33-42, BCSA, Johannesburg.

Matshiga, D.J., 2001, 'Christian education in the Baptist Convention of South Africa with special reference to churches in the Transvaal: A practical theological investigation', PhD thesis, University of Pretoria, Pretoria.
Mhlophe, P.F., 1990, 'The effects of apartheid on Baptist Convention pastors in South Africa', in D. Hoffmeister \& B. Gurney (eds.), The Barkly West national awareness workshop, pp. 53-57, BCSA, Johannesburg.

Mosley, E., 1973, Called to joy, Convention Press, Nashville, TN.

Msiza, P., 1997, 'Baptist church government', in L. Kretzschmar, P. Msiza \& J.' Nthane (eds.), Being a Baptist in South Africa today, pp. 58-64, BCC, Johannesburg.

Mugabe, H.J., 1995, 'Towards an Afro-centric gospel', in D. Hoffmeister \& L. Kretzschmar (eds.), Towards a holistic, Afro-centric and participatory understanding of the gospel of Jesus Christ, pp. 7-9, BCSA, Johannesburg.

Ngambi, H.C. 2004, 'African leadership: Lessons from the chiefs', in T Meyer \& I. Boninelli (eds.), Conversations in leadership, pp. 107-127, Knowres, Randburg.

Oates, W.E., 1987, 'The marks of a Christian leader', Southwestern Journal of Theology 29(2), 19-22.

Parker, G.K., 1982, Baptists in Europe: History \& confessions of faith, Broadman Press, Nashville, TN.

Pityana, B., 1995, 'Culture and the church: The quest for a new ecclesiology', in B. Pityana \& C. Villa-Vicencio (eds.), Being the church in South Africa today, pp. 87-99, SACC, Johannesburg.

Schelin, C., 2012, 'In a congregational way: The Baptist possibility of sacramental and radical democracy', Journal of European Baptist Studies 10(3), 22-36.

Schmidt, H.J., 1979, 'Portraits of pastoral leadership', Direction 8(2), 3-9.

Schnelle, U., 1998, The history and theology of the New Testament writings, Fortress Press, Minneapolis, MN.

Shelley, B.L., 1989, 'Congregationalism and American culture', Fidest et Historia 21(2), 38-50.

Wilkes, G.C., 1998, Jesus on leadership, Tyndale House Publishers, Carol Stream, IL.

Young, J.R., 1985, 'Shepherds, lead', Grace Theological Journal 6(2), 329-335. 